\title{
EFFECT OF PH AND VOLUME IN THE HATCHING OF RESISTANCE CYSTS OF THE SPECIES DENDROCEPHALUS BRASILIENSIS PESTA, 1921 (CRUSTACEA, ANOSTRACA)
}

\author{
ASTOLFI, A. C. M. N ${ }^{1 *}$; FERREIRA, M. G. A. ${ }^{1}$; CENTURIÃO, T. D. ${ }^{1}$; OLIVEIRA, B. L. M. C. ${ }^{1}$ \\ \& SILVA, W. M ${ }^{1}$.
}

1. Universidade Federal de Mato Grosso do Sul (UFMS)

*Corresponding author: angelchrismelo@gmail.com

\begin{abstract}
Astolfi, A. C. M. N.; Ferreira, M. G. A.; Centurião, T. D.; Oliveira, B. L. M. C. \& Silva, W. M. (2019). Effect of pH and Volume in the Hatching of Resistance Cysts of the Species Dendrocephalus brasiliensis Pesta, 1921 (Crustacea, Anostraca) Braz. J. Aquat. Sci. Technol. 23(1). eISSN 1983-9057. DOI: 13700/bjast.v23n1. Branchoneta is an option as live food for aquaculture and it is necessary to develop more studies to get information that makes possible its culture on a large scale. Our aim was to establish a method that results in a higher percentage hatching of $D$. brasiliensis. We analyzed if the cyst density could cause any significant difference in hatching; for that test we use 2 different conditions: (I) $15 \mathrm{ml}$ glass tube (T1, T2 and T3) with 25 (twenty-five) cysts/repetition; and (II) Erlenmeyer of $150 \mathrm{ml}$ (T4, T5, and T6) with 25 cysts/ repetition totaling 75 cysts/treatment, with triplicates to all treatments. We also tested 3 different $\mathrm{pH}$ conditions: acid $(\mathrm{pH}$ $3)$, neutral $(\mathrm{pH} 7 /$ distilled water) and alkaline $(\mathrm{pH} 8)$, all in natural light and temperature. We conclude that there is no difference between the treatments, for none of the conditions tested. But other results have to be considered as Hatching Speed index and the Average Hatching Time with best results for the treatments T3, T1 and T2, respectively. The density of $0.6 \mathrm{ml} / \mathrm{cyst}$ (glass tube) resulted in faster hatching, which shows the necessity of further studies to analyze the speed of hatching under different conditions of density. The relative frequency showed that the hatchings peak occurs in the second day. We conclude that $\mathrm{pH}$ and density, in this study, not influenced the beginning of the hatching process.
\end{abstract}

Key Words: Branchoneta, Cyst hatching, Aquaculture, Food production.

\section{INTRODUCTION}

Aquaculture is an alternative to the scenario of overexploitation of natural resources that can relieve pressure on stocks of wild fish (Ludwig et al., 1993; Stotz, 2000). The quality of fish feed is a key factor of aquaculture (Kong et al., 2020). Among the foods consumed by fish, live foods are an alternative rich in proteins, they contribute to digestive enzymes, stimulate endocrine responses, helps in the growth and survival of species (New, 1998; Zambonino-Infante \& Cahu, 2001; Mandal et al., 2009).

The species Dendrocephalus brasiliensis Pesta, 1921 (Crustacea, Anostraca), popularly known as branchoneta, stands out for presenting protein levels similar or superior to those of other organisms used in large-scale aquaculture, besides the greater biomass production when compared to Artemia ssp. (Lopes et al., 1998; 2007; Mai et al., 2008; Freita et al., 2017). Another important characteristic of $D$. brasiliensis is the rusticity, as it presents resistance cysts and the capacity of sex-changing (Lopes et al., 2011; Silva et al., 2013; Santos et al., 2019).

The species' natural habitat is semi-arid, which naturally has higher temperatures, and there are limited studies on techniques for improving hatching (Santos et al., 2019). Lopes et al. (1998) observed, in natural and nursery conditions, that in three days post-larval forms hatch and in one week, individuals with ovaries in the formation and eight days after hatching, the individuals are in adult form, with each female being able to deposit 100 to 230 cysts at a time.

Since the branchoneta can be an option as live food in aquaculture it is necessary to develop studies that aim to get the maximum information to make possible its creation on a large scale. Among the information necessary for the success in creating this crustacean is the development of techniques to achieve top hatch rates, which demands studies of hatching in different conditions. Thus, the $\mathrm{pH}$ analysis on extreme ranges (as the chosen acid pH3)is importanttoshowifthespecies hasthecapacity of hatching in such an extreme condition (Rojas et al., 2001); as also the comparison in neutral ( $\mathrm{pH} \mathrm{7)}$ and alkaline ( $\mathrm{pH} 8$ ), as tested or observed on other studies (Lopes et al., 2007; Pereira \& Santos Neto, 2010).

Another factor to be tested is the effect of density on the eclosion since there aren't many studies about this factor for this species; Da Silva (2016), discovered that sediment with over 2000 cysts in $300 \mathrm{ml}(0,15 \mathrm{ml} / \mathrm{cyst})$ of water presents reduced eclosion rate. Therefore, we tested whether the percentage of Dendrocephalus brasilisensis cysts hatching depends on density and $\mathrm{pH}$.

\section{MATERIAL AND METHODS}

We purchased a substrate with cysts of $D$. brasiliensis from the northeast of Brazil (Bahia State). 
As the cysts are mixed with sand and organic matter they required manual separation, which we performed with the aid of an Olympus SZ40 microscope. The cysts were removed one by one with a needle and stored directly in the glassware used in the experiment.

To analyze if the density of cysts could cause any significant difference in hatching, we test the same conditions of $\mathrm{pH}$ on both glassware, the glass tube that represents the density of $0.6 \mathrm{ml} / \mathrm{cyst}$, and the beaker with the density of $6 \mathrm{ml} /$ cyst. The treatments were composed of 75 (seventy-five) cysts, divided into 3 (three) replicates of 25 (twenty-five) cysts each. Both densities (tube glass $0.6 \mathrm{ml}$ and beaker $6 \mathrm{ml}$ ) were also tested for their hatching rate at 3 different $\mathrm{pH}$ conditions: acid $(\mathrm{pH} 3)$, neutral $(\mathrm{pH} 7)$ and alkaline $(\mathrm{pH} 8)$ in a room with the natural light condition, resulting in 6 treatments (Table 1).

Table 1. Different conditions of the volume of water and $\mathrm{pH}$ in the treatments used for testing the hatching percentage of Dendrocephalus brasiliensis Pesta, 1921 (Crustacea, Anostraca).

\begin{tabular}{ccc}
\hline Treatments & $\mathrm{pH}$ & Volume \\
\hline $\mathrm{T} 1$ & 3 & $15 \mathrm{ml}$ \\
$\mathrm{T} 2$ & 7 & $15 \mathrm{ml}$ \\
$\mathrm{T} 3$ & 8 & $15 \mathrm{ml}$ \\
$\mathrm{T} 4$ & 3 & $150 \mathrm{ml}$ \\
$\mathrm{T} 5$ & 7 & $150 \mathrm{ml}$ \\
$\mathrm{T} 6$ & 8 & $150 \mathrm{ml}$ \\
\hline
\end{tabular}

We prepared the mediums at different $\mathrm{pH}$ using specific buffers for $\mathrm{pH}$ stabilization; the phosphate buffer for $\mathrm{pH} 7$ and 8 and Citrate buffer for $\mathrm{pH} 3$ (Sorensen,1909; Lillie, 1948; Stoll \& Blanchard; 1990). We diluted the buffers in the distilled water and adjusted the $\mathrm{pH}$ using a portable $\mathrm{pH}$ meter device.

For the distribution of the experiment, it was entirely randomized. We packed the glass tubes in a metal rack and it disposed the Erlenmeyer side by side directly on the table. We exposed all experiments to natural lightening, since the room comprises a transparent ceiling. We exposed the experiments to sunlight and natural temperature variation since the room comprises a transparent, we chose the natural temperature because the Midwest region has an average high of $29.75^{\circ} \mathrm{C}$ (INMET, 2010). This temperature is close to the ideal for cultivation according to Gonçalves (2001), who found a survival rate of $92.2 \% D$. brasiliensis nauplii in effluent at a controlled temperature of $27^{\circ} \mathrm{C}$.

After 24 hours from the beginning of the experiment we start the counting of nauplii, through observation of individuals swimming in the different mediums, as also as individuals with no apparent mobility. The counting occurred always around 04:00 pm during seven days. On these data we tested the: Hatching percentage - H (\%); Hatch speed Index - HSI; and
Average hatching time $-\mathrm{AHT}$. The hatching percentage $(\mathrm{H}(\%))$ was calculated according to the formula:

$$
H(\%)=\left(t_{n} / t_{e}\right) * 100
$$

Where $t_{n}$ is the total number of cysts hatched; te is the total number of cysts used (Zanandrea, 2010).

To calculate the hatching speed of the branchoneta cysts, we adapted the formula of Maguire (1962). Thus, we have:

$$
\mathrm{HSI}=\sum\left(\mathrm{n}_{\mathrm{i}} / \mathrm{t}_{\mathrm{i}}\right)
$$

Where $n_{i}=$ number of cysts hatching at time $i$; $t_{i}=$ time in days of the beginning of the experiment, with " $i$ " varying in this experiment from 1 to 7 days.

For the average hatching time we adapted the formula of Labouriau (1983):

$$
A H T=\left(\sum n_{d} t_{i} / \sum n_{d}\right)
$$

Where $n_{d}=$ number of cysts hatched per day; $t_{i}=$ average incubation time, with $\mathrm{i}$ ranging, in this experiment, from 1-7 days. the formula:

The relative frequency was calculated using

$$
\left.R F=\left(n_{i}^{*} 100\right) / n_{t}\right)
$$

Where $n_{i}$ being the number of cysts hatched per day; $n_{t}$ the total number of cysts hatched. The results were submitted to an analysis of variance (Anova-Two way) with $5 \%$ of significance $(p<0.05)$.

\section{RESULTS AND DISCUSSION}

The results showed that there is no difference between the treatments $(p>0,05)$, therefore, the different $\mathrm{pH}$ did not influence the hatching rate, however, for both conditions of density, the maximum hatching and minimum hatching speed index values were obtained at neutral $\mathrm{pH}$. For the $15 \mathrm{ml}$ condition $(0,6 \mathrm{ml} / \mathrm{cyst})$, the hatching rate varied from 12 to $16 \%$ and for $150 \mathrm{ml}$ (6 ml/cyst) from $17.3 \%$ to $29 \%$ (Table 2 ).

Table 2. Hatching percentage of Dendrocephalus brasiliensis Pesta, 1921 (Crustacea, Anostraca) in different conditions - T1 (pH 3/Vol. 15ml); T2 (pH 7/Nol. 15ml); T3 (pH 8/Vol. 15ml; T4(pH 3/Vol. 150ml); T5 (pH 7/Nol. 150ml) e T6(pH 8/Vol. 150ml).

\begin{tabular}{cccc}
\hline Treatments & $\begin{array}{c}\text { Hatching } \\
(\mathrm{H} \%)\end{array}$ & $\begin{array}{c}\text { Hatching Speed } \\
\text { Index }\end{array}$ & $\begin{array}{c}\text { Average Hatching } \\
\text { Time }\end{array}$ \\
\hline T1 & $13.3 a$ & 0.92593 & 1.08 \\
T2 & $16 a$ & 0.75758 & 1.32 \\
T3 & $12 a$ & 1.08696 & 0.92 \\
T4 & $18.7 a$ & 0.65789 & 1.52 \\
T5 & $28 a$ & 0.35211 & 2.84 \\
T6 & $17.3 a$ & 0.60976 & 1.64 \\
\hline
\end{tabular}


The results show that different $\mathrm{pH}$ did not influence on the hatching rate of $D$. brasiliensis species. Such a result is similar to the found for Rojas et al., (2001) while studying the abiotic factors in the hatching of Moina micrura. The authors conclude that the $\mathrm{pH}$ tolerance and maximum hatching in such extreme $\mathrm{pH}$ range show the resistance capacity of the species to limit processes, usually used in aquaculture, and remaining viable and producing young to recolonize the environment. Lopes et al. (2007) affirm that the best hatching index occurred in the alkaline $\mathrm{pH} 8$, but those studies did not use different treatments with adjusted $\mathrm{pH}$, they just measure the $\mathrm{pH}$, therefore, the hatching rate found on those studies could be a result from other factors.

The speed and average time of hatching are interesting to the producer because $D$. brasiliensis naturally presents sparse hatching; then, to find out the best conditions with the highest speed index and shortest average time could make the production more attractive. Among all the treatments those with higher density (T1, T2 and T3) presented a higher hatching speed index and consequently a lower average time. According to Da Silva (2016), which tested hatching efficiency according to density, hatching rates of $D$. brasiliensis drastically decreases in density higher than $2000 / 300$ (cysts $/ \mathrm{ml}$ ); the density of $75 / 15$, used in this study, which had higher HSI and lower AHT shows that notonlytheamountofhatching mayberelated to the density but also the speed at which hatching takes place.

For the relative frequency (figure 1) the hatching peak happens on the second day, with one exception in T6 treatment when a distribution of the hatching peak trough the 2 and 3 days. Those peaks happened between temperatures of 32 and $22^{\circ} \mathrm{C}$.
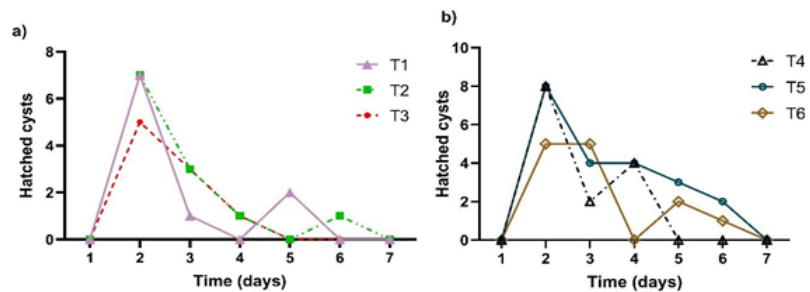

Figure 1. Total hatchings of Dendrocephalus brasiliensis (Crustacea, Anostraca) on different treatments ( $\mathrm{T} 1(\mathrm{pH} 3 / \mathrm{Vol}$. $15 \mathrm{ml}) ; \mathrm{T} 2(\mathrm{pH} 7 /$ Vol. 15ml); T3 (pH 8/Vol. 15ml; T4(pH 3/Vol. 150ml); T5 (pH 7/Nol. $150 \mathrm{ml}$ ) e T6(pH 8/Vol. 150ml)) in function of time (seven days).

De Vasconcellos (2010), studying branchoneta in climatic conditions in southeastern Brazil, got $80 \%$ of the hatcheries about 18 hours since the beginning of the experiment, at an average temperature of $32^{\circ} \mathrm{C}$. However, in our experiment, the peak hatching occurs on the second day, between 24 and 48 hours, with only one exception to the T6 treatment, where the peak hatching occurs between 48 and 72 hours. This difference may be related to genetic characteristics according to
Da Silva (2016), suggesting that the initial hatching of $D$. brasiliensis is influenced by a genetic character that causes different individuals to hatch at different times.

The relative frequency also shows that, from all treatments, we have the peak of hatchings on the second day, with the only T6 divided between the second and third days.

\section{CONCLUSION}

These results show that, in this study, $\mathrm{pH}$ and density not influenced the beginning of hatch. But, there are other conditions that should be considered since provides some advantages to the Producers as the $\mathrm{HSI}$ and $\mathrm{AHT}$; and the best results from those are $\mathrm{T} 3, \mathrm{~T} 1$, and $\mathrm{T} 2$, respectively. As the temperature conditions during this study varied, we suggest that it's important to develop new studies not only with controlled temperature but also with temperature variation.

The relative frequency showed the peak of hatchings on the second day, with no influence of $\mathrm{pH}$ and density. The non-influence of $\mathrm{pH}$ on hatching shows that the species is not limited to the extreme $\mathrm{pH}$ ranges, besides showing the species' ability to resist limiting processes and reaffirm its aptitude to be used on aquaculture.

\section{REFERENCES}

Da Silva, R.A.C. 2016. Cultivo de Dendrocephalus brasiliensis (Pesta, 1921) visando à aplicação em aquicultura. Tese de Doutorado. Universidade Federal de São Carlos - UFSCar. 140p.

De Vasconcellos, M.G. 2010. Características populacionais, desenvolvimento e produção de Dendrocephalus brasiliensis Pesta, 1921 sob as condições climáticas da região sudeste do país. Rev Bras Zoo. 12(1):125-132.

Freita, F.R.; Lucena, I.C.; Alencar, D.R.; Santos, I.J. \& Pinheiro, A.P. 2017. Occurrence of Dendrocephalus brasiliensis Pesta, 1921 (Crustacea, Anostraca) in the Caras river, southern Ceara, Brazil. An. Acad. Bras. Ciênc. 89(2): 1047-1049.

Gonçalves, J.L. 2001. Remoção de algas via alimentação pelo microcrustáceo Dendrocephalus brasiliensis (Crustacea: Anostraca). Dissertação de Mestrado. Universidade Federal de Mato Grosso do Sul - UFMS. 76p.

INMET. 2010. Normas climatológicas do Brasil. Instituto Nacional de Meteorologia. 1981-2010.

Kong, W.; Huang, S.; Yang, Z.; Shi, F.; Feng, Y. \& Khatoon, Z. 2020. Fish Feed Quality Is a Key Factor in Impacting Aquaculture Water Environment: Evidence from Incubator Experiments. Sci Rep. 10(1): 1-15. 
Labouriau, L.G. 1983. A germinação das sementes. Secretaria Geral da Organização dos Estados Americanos, Washington. 174p.

Lillie, R.D. 1948. Histopathologic Technique. The Blakiston Company, Philadelphia. 102p.

Lopes, J.P.; Da Silva, A.L.N.; Dos Santos, A.J.G \& Tenório, R.A. 1998. Branchoneta, uma notável contribuição à larvicultura e alevinagem de peixes carnívoros de água doce. Panorama da Aquicultura. 8(1): 31-34.

Lopes, J.P.; Gurgel, H.C.B.; Gálvez, A.O. \& Pontes C.S. 2007. Produção de cistos de "branchoneta" Dendrocephalus brasiliensis (Crustacea: Anostraca). Biotemas. 20(1): 33-39.

Lopes, J.P.; Gurgel, H.D.C.B.; Araujo, A. \& Pontes, C. S. 2008. Influência da inoculação de cistos na produção de biomassa de "branchoneta" Dendrocephalus brasiliensis Pesta, 1921 (Crustacea: Anostraca). Ciênc. Agrotec. 32(2): 598-603.

Lopes, J.P.; Gurgel, H.C.B. \& Pontes, C.S. 2011. Comportamento Reprodutivo de Dendrocephalus brasiliensis, Pesta 1921 (CRUSTACEA: ANOSTRACA). Rev. Ciência Animal Brasileira. 12(4): 617-625.

Ludwig, D.; Hilborn, R.; Walters, C. 1993. Uncertainty, resource exploitation, and conservation: lessons from history. Science. 260(5104): 17-36.

Maguire, J.D. 1962. Speed of germination aid in selection and evaluation for seedling emergence and vigor. Crop Science. 2(1): 176-177.

Mai, M.G.; Silva, T.A.S.; Almeida, V.L.S. \& Serafini, R.L. 2008. First record of the invasion of Dendrocephalus brasiliensis Pesta, 1921 (Crustacea: Anostraca: Thamnocephalidae) in São Paulo State, Brazil. Pan-Am. j. aquat. sci. 3(3): 269-274.

Mandal, S.C.; Das, P.; Singh, S.K.; Bhagabati, S.K. 2009. Feeding of aquarium fishes with natural and artificial foods: available options and future needs. Aqua International. 3(1): 20-23.

New, M.B. 1998. Global aquaculture: Current trends and challenges for the 21st century. J World Aquacult Soc. 30(1): 63-79.

Pereira, D.C. \& Santos-Neto, M. A. 2010. Influência do Ácido Ascórbico e dos ĺons $\mathrm{Ca}+2$ na eclosão de cistos do Anostraca Branconeta (Dendrocephalus brasiliensis PESTA, 1921). Rev. Bras. Eng. Pesca 5(3): 28-41.

Rojas, N.E.T.; Marins, M.A. \& Rocha, O. 2001. The effect of abiotic factors on the hatching of Moina micrura Kurz, 1874 (Crustacea: Cladocera) ephippial eggs. Braz J Biol. 61(3):371-376.

Santos, L.L.S.; Cahú, T.B.; Teixeira, D.I.; Ribeiro, K.; Brayner, F.A.; Alves, L.C.; ... \& Bezerra, R.S. 2019. A new process for nauplius production of the freshwater fairy-shrimp Dendrocephalus brasiliensis (Pesta, 1921) and the effect of enzymatic and chemical treatment on hatching. Aquaculture. 512(1):734350.

Silva, S.M.B.; Santos, L.B.G.D.; Lopes, J.P.; Gálvez, A.O. \& Coimbra, M.R.M. 2013. Sexual reproduction in freshwater fairy shrimp, Dendrocephalus brasiliensis (Pesta, 1921) inferred by Amplified Fragment Length Polymorphism markers. Ciênc. Rural. 43(6): 1076-1081.

Sorensen, S.P.L. 1909. Über die Messung und die Bedeutung der Wasserstoffionen-koncentration bei enzymatischen Prozessen. Biochem. Zeitschr. 21(1):131-304.

Stoll, V.S. \& Blanchard, J.S. 1990. Buffers: principles and practice. Methods In Enzymology. 24-38pp.

Stotz, W. 2000. When aquaculture restores and replaces an overfished stock: Is the conservation of the Species assured? The case of the scallop Argopecten purpuratus in Northern Chile. Aqua. International. 8(2): 237-247.

Zambonino Infante, J.L \& Cahu, C.L. 2001. Ontogeny of the gastrointestinal tract of marine fish larvae, Comp. Biochem. and Physiol. 130(4): 477-487.

Zanadrea, A.C.V. 2010. Eclosão de branchonetas Dendrocephalus brasiliensis em condições de laboratório. Universidade Federal de Santa Catarina - UFSC. 22p.
Submetido: Dezembro/18 Revisado: Junho/2020 Aceito:Junho/2020 Publicado: 24/09/2020 